\title{
Neutralization effect of slag on the acid rock drainage
}

\author{
Inwoo Baek', Jaegon Kim², Youngsuk Song ${ }^{2}$ and Taehyung Kim ${ }^{3 *}$
}

\section{${ }^{*}$ Correspondence:}

kth67399@kmou.ac.k

${ }^{3}$ Department of Civil

Engineering, Korea Maritime

and Ocean University,

Busan 49112, South Korea

Full list of author information

is available at the end of the

article

\begin{abstract}
Aims/hypothesis: Pohang Tertiary mudstone presents the issue of acid rock drainage. This study analyzed the capacity of a mixed slag (70\% steel slag $+30 \%$ blast furnace slag) to neutralize Pohang Tertiary mudstone's acid rock drainage.

Methods: Element analysis, acid neutralization capacity (ANC) test, and net acid generation (NAG) test were conducted on Pohang Tertiary mudstone samples and the mixed slag. The XRF analysis and the XRD analysis on the mixed slag were conducted to measure the $\mathrm{CaO}$ content, which indicates the potential of the mixed slag as an acid-neutralizing agent.
\end{abstract}

Results: According to the analysis results on the Pohang Tertiary mudstone samples, the total sulfur content was high, which indicates a high risk of acid rock drainage generation. Although there were slight deviations between the samples, overall, the mudstone exhibited a high acid rock drainage generation capacity. The XRF analysis of mixed slag results showed high amounts of $\mathrm{CaO}$ content. From the XRD analysis graph, it was clear that a high proportion of minerals with Ca-compounds consisting of basic substances were present. The neutralization capacity of the mixed slag on Pohang Tertiary mudstone was determined by the relationship between maximum potential acidity (MPA) and acid neutralization capacity (ANC). For instance, the mixed slag of $4.5 \%$ effectively neutralizes a sulfur content of $1 \%$.

Keywords: Acid rock drainage, Pohang tertiary mudstone, Sulfur content, Acid neutralization capacity maximum potential acidity

\section{Introduction}

Pohang Tertiary mudstone presents the issue of acid rock drainage as it readily reacts with oxygen and water during the weathering process. In general, acid rock drainage adversely affects the surrounding environment as well as the stability, lifespan, and landscape of structures $[1,3]$. Acid rock drainage is a result of oxidation by sulfide minerals in the rock. Sulfide minerals are produced through various geological processes, such as diagenesis, precipitation from hydrothermal solution, and reaction between host rock and hydrothermal solution. A notable sulfide mineral is pyrite (FeS2), which remains stable if it is not in contact with the atmosphere. However, when it is exposed to the atmosphere during earthwork, it reacts with oxygen and water to produce acid rock drainage, which produces sulfuric acid and metal precipitates [2]. Evaluating the

(c) The Author(s) 2021. This article is licensed under a Creative Commons Attribution 4.0 International License, which permits use, sharing adaptation, distribution and reproduction in any medium or format, as long as you give appropriate credit to the original author(s) and the source, provide a link to the Creative Commons licence, and indicate if changes were made. The images or other third party material in this article are included in the article's Creative Commons licence, unless indicated otherwise in a credit line to the material. If material is not included in the article's Creative Commons licence and your intended use is not permitted by statutory regulation or exceeds the permitted use, you will need to obtain permission directly from the copyright holder. To view a copy of this licence, visit http://creativeco mmons.org/licenses/by/4.0/. 
acid rock drainage is necessary to determine the suitability of using Pohang Tertiary mudstone as a road subbase material. In this study, the capacity of tertiary mudstone to generate acid rock drainage and the capacity of a mixed slag (70\% steel slag $+30 \%$ blast furnace slag) to neutralize acid rock drainage of Pohang Tertiary mudstone were determined.

\section{Methods}

\section{Materials}

The Pohang Tertiary mudstone samples were obtained from a construction site located in a residential area development site in Iin-ri, Heunghae-eup, Pohang, North Gyeongsang Province. This area's bedrock has a high potential for generating acid rock drainage (KIGAM, 2019). The samples, which were obtained from four locations, were fabricated according to the quartering method. The samples were named EN-R1 R4, with 'EN' referring to Iin-ri and ' $R$ ' referring to 'rock.' The samples were completely dried and ground to 200 mesh $(<75 \mathrm{~mm})$ or smaller for the tests.

\section{Testing methods}

An elemental analyzer (vario MACRO cube) was used to analyze the total sulfur content. $100 \mathrm{mg}$ of the sample that was completely dried in a hot air oven and ground to a particle size 200 mesh or smaller was used. The contents of $\mathrm{C}, \mathrm{H}, \mathrm{N}$, and $\mathrm{S}$ (\%) were analyzed via the $850 \sim 1150{ }^{\circ} \mathrm{C}$ combustion method. The maximum potential acidity (MPA) was calculated using the analyzed sulfur content (\%) with Eq. (1) proposed by the ARD Test Handbook [4].

$$
\operatorname{MPA}\left(\operatorname{kg} \frac{\mathrm{H}_{2} \mathrm{SO}_{4}}{t}\right)=\operatorname{Total} S(\%) \times 30.6
$$

The acid neutralization capacity (ANC) test evaluates the ability of constituent minerals to neutralize acidic rock drainage arising from sulfide minerals in the sample. First, the presence of $\mathrm{CaCO}_{3}$ is confirmed through the fizz test by dropping three to four drops of $8 \% \mathrm{HCl}$ to the sample. The concentrations and volumes of $\mathrm{HCl}$ and $\mathrm{NaOH}$ are determined. ANC is then calculated using Eq. (2) [5].

$$
A N C=\frac{Y \times M_{H C l}}{w_{t}} \times C
$$

where, $\mathrm{Y}=($ Vol. of $\mathrm{HCl}$ added $)-($ Vol. of $\mathrm{NaOH}$ titrated $) \times \mathrm{B}$

$$
\mathrm{B}=\frac{(\text { Vol. of } \mathrm{HCl} \text { Blank })}{(\text { Vol. of NaOH titrated Blank })}
$$

Here, $\mathrm{M}_{\mathrm{HCl}}$ is the mole concentration, $\mathrm{w}_{\mathrm{t}}$ is the weight of the sample, and $\mathrm{C}=49.0(\mathrm{~kg}$ of $\mathrm{H}_{2} \mathrm{SO}_{4} / \mathrm{t}$ ).

For the net acid generation (NAG) test, sulfide minerals in the sample are forcibly oxidized by diluting $15 \% \mathrm{H}_{2} \mathrm{O}_{2}$ with sub-200 mesh mudstone sample with a ratio of 100:1 and reacting for at least $12 \mathrm{~h}$. The reacted solution is slowly heated to $80 \sim 90{ }^{\circ} \mathrm{C}$, and distilled water is added to maintain the volume of the dilution ratio. This process 
decomposes the remaining $\mathrm{H}_{2} \mathrm{O}_{2}$. Once the decomposition process is complete, $\mathrm{NaOH}$, with a predetermined concentration depending on the NAG $\mathrm{pH}$, is added to the solution to increase the $\mathrm{pH}$ to 4.5 via titration. If $\mathrm{NAG} \mathrm{pH}$ is over 2, titrate with $0.1 \mathrm{M} \mathrm{NaOH}$. If NAG pH is lower than or equal to 2, titrate with $0.5 \mathrm{M} \mathrm{NaOH}$. Upon the completion of the test, the NAG value is calculated according to Eq. (3), and the potential acid generation of the sample is calculated according to Table 1 [4].

$$
\mathrm{NAG}\left(\mathrm{kg} \frac{\mathrm{H}_{2} \mathrm{SO}_{4}}{t}\right)=\frac{\text { put } \mathrm{NaOH} \operatorname{Vol}(\mathrm{ml}) \times \text { put } \mathrm{NaOH}(\mathrm{M}) \times 49}{\text { Sample weight }(g)}
$$

\section{Results and discussion}

\section{Probability of mudstone acid rock drainage generation}

The analysis results of the $\mathrm{C}, \mathrm{H}, \mathrm{N}$, and $\mathrm{S}$ contents (\%) in the mudstone samples were obtained using an elemental analyzer. All sulfur is assumed to exist in the form of pyrite, and Eq. (1) is used to calculate the maximum potential acidity (MPA). Although the sulfur content values of each location varied up to twofold, in general, the values were greater than $1 \%$, indicating a high risk of acid rock drainage generation [2]. The measurement results of the net acid generation (NAG) of each sample also show that sample EN-R4 exhibited the highest NAG value, followed in order by EN-R1, EN-R3, and EN-R2 (Table 1).

\section{Analysis of the neutralization capacity of the mixed slag}

According to the unified soil classification system, the mixed slag gains were classified as GP (poorly-graded gravel). By the XRF analysis results, there was a low amount of $\mathrm{SiO}_{2}$ detected (18.05\%). In contrast, there were high amounts of $\mathrm{Fe}_{2} \mathrm{O}_{3}$ and $\mathrm{CaO}$ measured. This result is due to the slag being produced in steel mills, resulting in high amounts of metal oxides. $\mathrm{CaO}$ was present in an abundant amount, which may signify the slag's potential as an acid neutralizer. Melilite, apatite, olivine, and iron oxide compounds were measured according to the XRD pattern. A high proportion of minerals with $\mathrm{Ca}$ - compounds consisting of basic substances were also detected. According to mixed slag's inductively coupled plasma atomic emission spectroscopy (ICP-AES) measured values, a small concentration of chrome was detected $(0.35 \mathrm{ppm})$. As a characteristic of a steel mill slag, a high concentration of $\mathrm{Ca}^{2+}$ was detected with a measured value of $60.50 \mathrm{ppm}$, indicating its potential as a neutralizing agent.

Table 1 Acid base accounting test results of the Pohang Tertiary mudstone samples

\begin{tabular}{|c|c|c|c|c|c|c|}
\hline Sample & $\begin{array}{l}\mathrm{MPA} \\
\left(\mathrm{kg} \mathrm{H}_{2} \mathrm{SO}_{4} / \mathrm{t}\right)\end{array}$ & $\begin{array}{l}\text { NAPP } \\
\text { (MPA-ANC) }\end{array}$ & $\frac{A N C}{M P A}$ & $\begin{array}{l}\text { NAG } \\
\left(\mathrm{kg} \mathrm{H}_{2} \mathrm{SO}_{4} / \mathrm{t}\right)\end{array}$ & $\frac{N A G}{N A P P}$ & $\begin{array}{l}\text { Geochemical } \\
\text { classification }\end{array}$ \\
\hline EN-R1 & 84.64 & 63.19 & 0.25 & 27.03 & 0.43 & PAF \\
\hline EN-R2 & 30.36 & -31.34 & 2.03 & 2.94 & -0.09 & UC \\
\hline EN-R3 & 38.80 & -7.18 & 1.19 & 13.89 & -1.93 & UC \\
\hline EN-R4 & 51.21 & 37.85 & 0.26 & 37.64 & 0.99 & PAF \\
\hline
\end{tabular}

Note 1: The safety factor (ANC/MPA) is an indicator of the relative safety margin regarding acid rock drainage. Based on a safety factor $=1$, it is considered safe if the value is greater than 1, and unsafe if the value is less than 1

Note 2: PAF (Potentially acid forming) indicates a high probability of acid rock drainage generation. UC means uncertain 


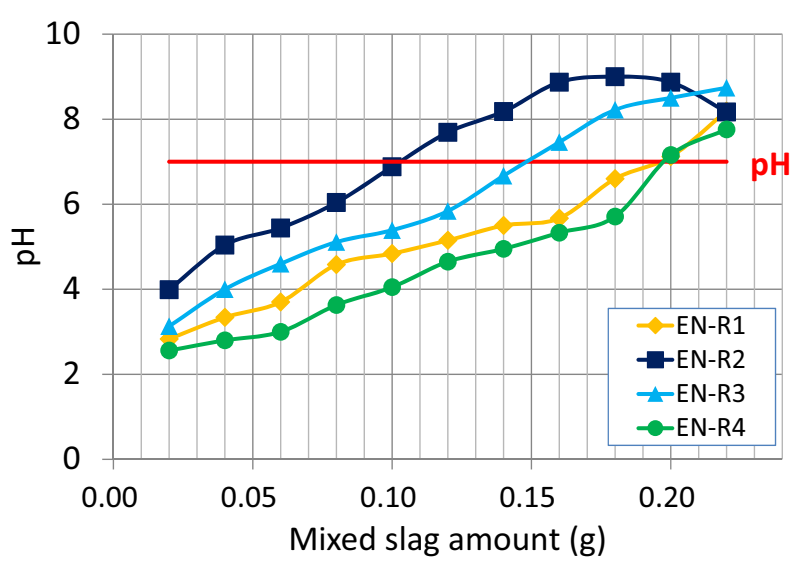

Fig. $1 \mathrm{pH}$ change of Pohang Tertiary mudstone samples according to the addition of mixed slag

Table 2 Required mixed slag amount by sulfur

\begin{tabular}{lllllll}
\hline Sample & $\begin{array}{l}\text { Weight } \\
(\mathbf{g})\end{array}$ & $\begin{array}{l}\text { Initial } \\
\mathbf{p H}\end{array}$ & $\begin{array}{l}\mathbf{S}(\mathbf{g}) \\
\text { in weight }\end{array}$ & $\begin{array}{l}\text { Aver } \\
\mathbf{S}(\mathbf{g})\end{array}$ & $\begin{array}{l}\text { Mixed slag(g) } \\
\text { to pH 7 }\end{array}$ & $\begin{array}{l}\text { Aver } \\
\text { Mixed slag (g) }\end{array}$ \\
\hline EN-R1 & 1.2503 & 2.83 & 0.036 & 0.021 & 0.196 & 0.161 \\
EN-R2 & 1.2511 & 3.99 & 0.012 & & 0.104 & \\
EN-R3 & 1.2517 & 3.13 & 0.016 & & 0.148 & \\
EN-R4 & 1.2514 & 2.56 & 0.021 & & 0.196 & \\
\hline
\end{tabular}

The neutralization capacity values of the mixed slag were obtained using the relationship between maximum potential acidity (MPA) and acid neutralization capacity (ANC). With the ANC of pure limestone $\left(\mathrm{CaCO}_{3}\right)$ as a reference, the ANC value of the mixed slag was calculated as 693.9. The proportion of mixed slag to neutralize a sulfur content of $1 \%$ was calculated to be $4.5 \%$ using the neutralization relation equation.

Another test method of analyzing neutralization capacity involves periodically adding small amounts of mixed slag to the mudstone samples that were used in the NAG pH tests. According to the test, an average of $0.161 \mathrm{~g}$ of mixed slag is required to neutralize each of the samples to $\mathrm{pH} 7$ (Fig. 1). Therefore, the ratio between the amount of mixed slag (g) that is added and the average sulfur content was calculated as 1:7.67. The same ratio was produced by the test results based on weight and the previous test based on percentages. The mixed slag amount required for neutralization according to the sulfur content was verified (Table 2).

\section{Conclusions}

In this study, laboratory experiments were conducted to determine the acid rock drainage neutralization capacity of a mixed slag $(70 \%$ steel slag $+30 \%$ blast furnace slag) against Pohang territory mudstone.

1. According to the analysis results on the Pohang territory mudstone, the total sulfur content was high, which in turn indicates a high risk of acid rock drainage generation reflected by a maximum potential acidity (MPA) higher than 1\%. All in all, although 
there were slight deviations between the samples, overall, the samples exhibited high acid rock drainage generation capacities.

2. The XRF analysis of mixed slag results showed high amounts of $\mathrm{Fe}_{2} \mathrm{O}_{3}$ and $\mathrm{CaO}$ were measured. The $\mathrm{CaO}$ content was especially high, indicating the potential of the mixed slag as an acid-neutralizing agent. From the XRD analysis graph, a high proportion of minerals with $\mathrm{Ca}$ - compounds consisting of basic substances were present.

3. The relationship between maximum potential acidity (MPA) and acid neutralization capacity (ANC) was used to analyze the mixed slag's neutralization capacity in the case $4.5 \%$ mixed slag is applied to neutralize $1 \%$ sulfur content in the tertiary mudstone samples. As a result, the neutralization capacity of the mixed slag was verified.

Acknowledgements

This work was supported by the Korea Institute of Geoscience and Mineral Resources (KIGAM) funded by the Ministry of Science and ICT of Korea under Grant GP2017-041-2019.

\section{Author details}

${ }^{1}$ Department of Civil and Environmental Engineering, Korea Maritime and Ocean University, Busan 49112, South Korea.

${ }^{2}$ Geo-Environmental Hazard Research Center, Korea Institute of Geoscience and Mineral Resources, Daejeon 34132,

South Korea. ${ }^{3}$ Department of Civil Engineering, Korea Maritime and Ocean University, Busan 49112 , South Korea.

Received: 15 August 2020 Accepted: 4 November 2020

Published online: 09 January 2021

\section{References}

1. KIGAM (2019) Technology development for damage reduction and ecosystem restoration in acid drainage producing construction site, GP2017-041-2019, p 160

2. Kim JG (2007) Acid drainage and damage reduction strategy in construction site: an introduction. Econ Environ Geol 50:651-660

3. Lee GM, Kim JG, Lee JS, Chon CM, Park SG, Kim TH, Ko GS, Kim TK (2005) Generation characteristics and prediction of acid rock drainage (ARD) of cut slope. Econ Environ Geol 38:91-99

4. Smart R, Skinner WM, Levay G, Gerson AR, Thomas JE, Sobieraj H, Schumann R, Weisener, CG, Weber PA, Miller SD, Stewart WA (2002) ARD test handbook: Project P387A, A prediction and kinetic control of acid mine drainage. Melbourne: AMIRA international Ltd., pp A4-8, D3-4.

5. Sobek AA, Schuller WA, Freeman JR, Smith RM (1978) Field and laboratory methods applicable to overburdens and mine soils, EPA 600/2-78-054. U.S. Environmental Protection Agency. Cincinnati, OH, pp 47-50

\section{Publisher's Note}

Springer Nature remains neutral with regard to jurisdictional claims in published maps and institutional affiliations.

\section{Submit your manuscript to a SpringerOpen ${ }^{\circ}$ journal and benefit from:}

- Convenient online submission

- Rigorous peer review

- Open access: articles freely available online

- High visibility within the field

Retaining the copyright to your article

Submit your next manuscript at $>$ springeropen.com 